\title{
UPAYA GURU DALAM MENINGKATKAN PRESTASI BELAJAR AKUNTANSI MENGGUNAKAN MODEL PROBLEM BASED LEARNING PEMBELAJARAN AKUNTANSI KOMPETENSI MENGELOLA KARTU PERSEDIAAN PADA SISWA KELAS XI AKUNTANSI SMK NEGERI 1 SAMBAS TAHUN AJARAN 2017/2018
}

\author{
ELLYZARD \\ SMK Negeri 1 Sambas \\ e-mail.Ellyzard87@gmail.com
}

\begin{abstract}
ABSTRAK
Penelitian ini bertujuan untuk mengetahui peningkatan prestasi belajar akuntansi pada kompetensi mengelola kartu persediaan dengan penerapan model pembelajaran problem based learning. Jenis penelitian ini yaitu penelitian tindakan kelas yang dilaksanakan dalam dua siklus. Tiap siklus terdiri dari empat tahap, yaitu perencanaan, tindakan, pengamatan, dan refleksi. Subjek penelitian ini adalah siswa kelas XI Akuntansi. Hasil penelitian menunjukkan bahwa: (1) Model Pembelajaran Problem Based Learning dapat meningkatkan Prestasi Belajar Akuntansi Siswa pada Kompetensi Mengelola Kartu Persediaan, terbukti dari nilai rata-rata prestasi belajar Akuntansi sebelum dilakukan tindakan adalah 69,36 dengan persentase ketercapaian KKM sebesar 40,91\%, setelah dilakukan tindakan pada siklus I nilai rata-rata mengalami peningkatan sebesar 1,59 menjadi 70,95 dengan persentase ketercapaian KKM sebesar 61,90\%. Pada siklus II nilai rata-rata siswa meningkat menjadi 93,86 (2) Penerapan Model Pembelajaran Problem Based Learning dalam pembelajaran Akuntansi kompetensi Mengelola Kartu Persediaan mendapatkan respon yang positif dari siswa kelas XI Akuntansi SMK Negeri 1 Sambas.
\end{abstract}

Kata Kunci: Prestasi belajar, problem based learning, kartu persediaan

\section{PENDAHULUAN}

Pendidikan sebenarnya merupakan suatu rangkaian peristiwa yang kompleks. Peristiwa tersebut merupakan suatu rangkaian kegiatan komunikasi antar manusia sehingga manusia itu tumbuh sebagai pribadi yang utuh. Selain itu dalam dunia pendidikan, proses belajar mengajar merupakan proses yang bisa diterapkan. Mengajar dan belajar merupakan proses kegiatan yang tidak dapat dipisahkan. Proses belajar mengajar yang berkembang di kelas umumnya ditentukan oleh peran guru dan siswa sebagai individu-individu yang terlibat langsung di dalam proses tersebut. Prestasi belajar siswa itu sendiri banyak tergantung pada cara guru menyampaikan pelajaran pada anak didiknya. Oleh karena itu kemampuan serta kesiapan guru dalam mengajar memegang peranan penting bagi keberhasilan proses belajar mengajar pada siswa prestasi belajar siswa merupakan hal yang sangat penting untuk diperhatikan oleh guru.

Sardiman AM. (2011: 45) Prestasi belajar merupakan muara dari proses pembelajaran, yang merupakan salah satu bagian dari proses pendidikan dengan guru sebagai pemegang peranan utama. Pentingnya peranan guru dalam proses pembelajaran mengharuskan guru dapat berpikir cerdas dalam mengemas kegiatan pembelajaran yang sedemikian rupa sehingga siswa dapat dengan mudah menyerap ilmu pengetahuan yang guru sampaikan.

Setyorini (2011) penggunaan metode yang tepat dalam proses pembelajaran sangat mempengaruhi keberhasilan proses pembelajaran. Namun kebanyakan sistem pembelajaran yang ada di sekolah saat ini masih mengarah pada metode pembelajaran ceramah. Padahal materi yang dapat dikuasai peserta didik sebagai hasil dari ceramah akan terbatas pada apa yang dikuasai guru, dan materi yang disampaikan oleh guru tidak akan terserap secara sempurna. Kelemahan ini merupakan kelemahan yang sering muncul ketika guru melakukan kegiatan pembelajaran dengan metode ceramah. Guru yang tidak mempunyai kemampuan menjelaskan dengan baik akan menyebabkan peserta didik menjadi cepat bosan dengan kegiatan 
pembelajaran, dan juga akan sulit bagi guru untuk mengetahui apakah seluruh peserta didik sudah memahami materi yang disampaikan oleh guru. Hal ini terjadi karena setiap peserta didik mempunyai cara yang berbeda dalam menangkap materi pelajaran, tidak hanya melalui pendengaran saja.

SMK Negeri 1 Sambas merupakan salah satu sekolah negeri yang mempunyai kompetensi kejuruan Akuntansi. Penelitian ini memfokuskan pada program keahlian Akuntansi kelas XI Akuntansi. Observasi yang peneliti lakukan di SMK Negeri 1 Sambas menunjukkan bahwa prestasi belajar Akuntansi siswa kelas XI Akuntansi masih rendah. Kemampuan yang dimiliki siswa kelas XI Akuntansi dalam penguasaan materi Akuntansi yang diberikan oleh guru masih kurang optimal. Hal ini ditandai dengan data yang menunjukkan masih banyaknya siswa yang tidak mampu mencapai Kriteria Ketuntasan Minimal (KKM) pada saat dilaksanakan ulangan harian, Ujian Tengah Semester, dan Ujian Semester pada semester gasal tahun ajaran 2013/2014. Nilai KKM pada mata pelajaran produktif Akuntansi di SMK Negeri 1 Sambas adalah sebesar 75 .

Berdasarkan data dari rata-rata nilai ulangan harian siswa kelas XI Akuntansi SMK Negeri 1 Sambas pada semester 1 tahun ajaran 2013/2014 hanya 6 siswa dari 22 siswa yang mampu mencapai nilai KKM yang besarnya 75 atau sekitar $73 \%$ siswa harus mengikuti program remidial. Selain itu masih ada siswa yang tidak mampu menyelesaikan tugas dengan tepat waktu dan mendapat nilai rendah pada setiap tugas Akuntansi yang diberikan oleh guru. Ketika guru memberikan tugas, siswa selalu mengeluh dan enggan untuk mengerjakan tugas, sehingga hasilnyapun tidak maksimal. Ketika Ujian Tengah Semester siswa yang mencapai KKM berjumlah 9 siswa atau sekitar $41 \%$ siswa yang nilainya mencapai 75 atau lebih.

Pada saat Ujian Semester Ganjil yang dilaksanakan pada bulan Desember 201, nilai ujian Akuntansi yang mencapai KKM 9 orang siswa atau sekitar $41 \%$ dari seluruh siswa. Permasalahan yang dialami setiap siswa yang menyebabkan rendahnya prestasi belajar. Permasalahan tersebut sebenarnya sangat kompleks karena setiap siswa memiliki masalah yang berbeda-beda. Siswa mempunyai cara yang berbeda dalam memahami dan menangkap suatu materi pelajaran yang diberikan oleh guru. Oleh karena itu sebagai seorang guru harus memiliki keterampilan dalam mengajar dan menyampaikan materi yang disampaikan kepada siswa. Salah satu keterampilan dan kemampuan seorang guru adalah harus tepat dalam pemilihan metode atau model pembelajaran yang akan digunakan. Metode yang digunakan di kelas XI Akuntansi SMK Negeri 1 Sambas masih konvensional yaaitu metode ceramah dan latihan soal. Metode tersebut membuat siswa menjadi cepat bosan dan jenuh, apalagi banyak siswa yang berpendapat bahwa akuntansi adalah pelajaran yang sulit. Apalagi tidak semua materi sesuai disampaikan dengan metode ceramah. Ada materi pelajaran yang membutuhkan penalaran siswa dalam memahaminya.

Mata pelajaran Akuntansi yang juga berada di jam pelajaran terakhir menyebabkan minat belajar Akuntansi siswa juga semakin menurun. Hal ini terjadi karena rendahnya aktivitas siswa yang hanya mendengarkan dan menulis penjelasan materi dari guru tanpa aktivitas lain yang mampu membangkitkan semangat siswa seperti berdiskusi, tanya jawab, dan sebagainya. Semangat dan motivasi siswa yang menurun ditandai dengan sikap siswa yang tidak memperhatikan pelajaran, cenderung mengobrol dan meletakkan kepala di atas meja, bahkan ada beberapa siswa yang mengatakan kepada guru mata pelajaran Akuntansi bahwa mereka merasa jenuh. Keadaan seperti tersebut tentunya akan berdampak pada tingkat penguasaan materi siswa dan juga berdampak pada prestasi siswa Hal ini membuat diperlukannya model pembelajaran yang sesuai dengan situasi, kondisi siswa dan lingkungan belajar serta dapat membuat siswa menjadi aktif, interaktif, dan kreatif dalam proses pembelajaran. Selain itu perlunya menyesuaikan materi pelajaran dengan model pembelajaran yang akan digunakan, sehingga siswa akan lebih mudah untuk menyerap materi pelajaran yang disampaikan oleh guru. Model pembelajaran yang aktif, interaktif ini tentu tidak bersifat satu arah, yaitu dari guru saja seperti pada metode ceramah, namun juga akan menghasilkan hubungan timbal balik 
(hubungan dua arah) antara siswa dengan guru. pada saat proses kegiatan pembelajaran karena siswa dituntut untuk berpartisipasi aktif

\section{METODE PENELITIAN}

Prosedur Penelitian Tindakan Kelas (PTK) dapat dilaksanakan melalui empat langkah utama yaitu: perencanaan (planning), pelaksanaan (acting), pengamatan (observing) dan refleksi (reflecting). Empat langkah utama dalam pelaksanaan Penelitan Tindakan Kelas (PTK) sering disebut dengan istilah satu siklus (Susilo, Herawati.dkk, 2009:19). Untuk lebih jelas berikut ini dikemukakan model siklus Penelitian Tindakan Kelas (PTK):

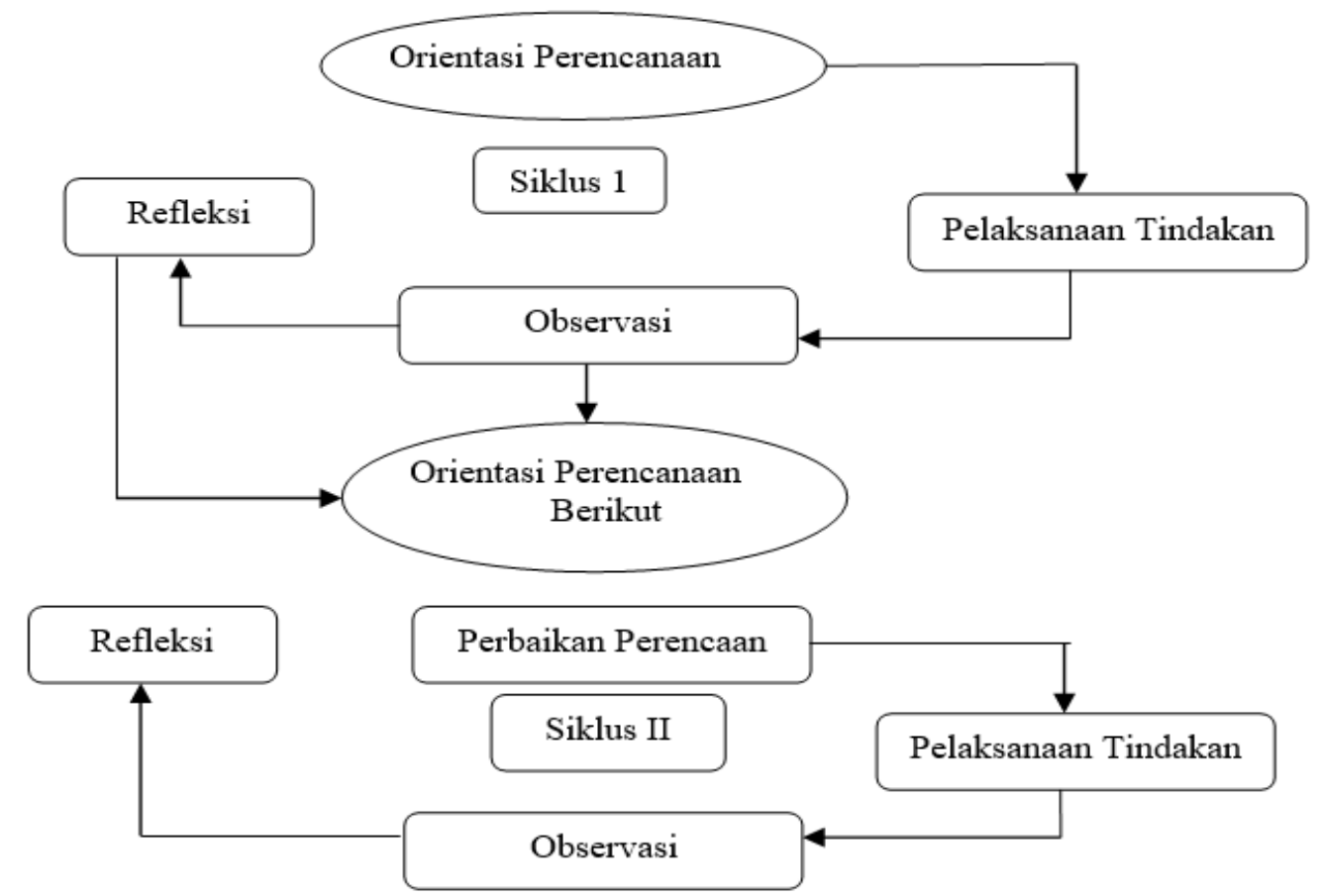

Gambar 1. Model siklus Penelitian Tindakan Kelas (PTK)

Hasil observasi dianalisis dengan analisis deskriptif berdasarkan hasil observasi dan refleksi dengan indikator kinerja peserta didik dalam pembelajaran. Adapun Indikator kinerja peserta didik dalam pembelajaran dapat dibuat dalam bentuk tabel sebagai berikut:

Tabel 1. Kisi-kisi Soal Evaluasi Siklus I

\begin{tabular}{|c|c|c|c|}
\hline Indikator & Materi Pelajaran & $\begin{array}{l}\text { Bentuk } \\
\text { Soal }\end{array}$ & $\begin{array}{l}\text { Aspek yang } \\
\text { Diukur }\end{array}$ \\
\hline $\begin{array}{l}\text { Memverivikasi } \\
\text { data mutasi } \\
\text { persediaan } \\
\text { bahan baku } \\
\text { Membukukan } \\
\text { data mutasi } \\
\text { persediaan } \\
\text { bahan baku } \\
\text { (unit dan } \\
\text { nominal) } \\
\text { dengan benar }\end{array}$ & $\begin{array}{l}\text { a. Metode pencatatan } \\
\text { persediaan bahan } \\
\text { baku } \\
\text { b. Format kartu } \\
\text { persediaan bahan } \\
\text { baku } \\
\text { c. Prosedur } \\
\text { pencatatan } \\
\text { persediaan bahan } \\
\text { baku }\end{array}$ & $\begin{array}{l}\text { Pilihan } \\
\text { Ganda } \\
\text { Uraian }\end{array}$ & $\begin{array}{l}\text { Pengetahuan } \\
\text { Pemahaman } \\
\text { Penerapan } \\
\text { Analisa }\end{array}$ \\
\hline
\end{tabular}


Tabel 2. Kisi-kisi Soal Evaluasi Siklus II

\begin{tabular}{|l|l|l|l|}
\hline Indikator & Materi Pelajaran & $\begin{array}{l}\text { Bentuk } \\
\text { Soal }\end{array}$ & $\begin{array}{l}\text { Aspek yang } \\
\text { Diukur }\end{array}$ \\
\hline $\begin{array}{l}\text { Menyajikan } \\
\text { laporan } \\
\text { persediaan } \\
\text { bahan baku } \\
\text { sesuai dengan } \\
\text { format yang } \\
\text { ditetapkan } \\
\text { Mengidentifikasi } \\
\text { saldo } \\
\text { persediaan } \\
\text { bahan baku }\end{array}$ & $\begin{array}{l}\text { a. } \begin{array}{l}\text { Bentuk laporan } \\
\text { persediaan bahan } \\
\text { baku } \\
\text { laporan } \\
\text { persediaan bahan }\end{array} \\
\text { baku }\end{array}$ & $\begin{array}{l}\text { Pilihan } \\
\text { Ganda } \\
\text { Uraian }\end{array}$ & $\begin{array}{l}\text { Pengetahuan } \\
\text { Pemahaman } \\
\text { Penerapan } \\
\text { Analisa }\end{array}$ \\
\\
\hline
\end{tabular}

\section{HASIL DAN PEMBAHASAN PENELITIAN}

\section{Hasil Penelitian Siklus I}

Berdasarkan pengamatan yang peneliti lakukan terhadap guru sebagai kolabolator yang melaksanakan dan mengelola kelas pada siklus I dalam proses pembelajaran dengan menerapkan Model Pembelajaran Problem Based Learning diperoleh data sebagai berikut: Pada pertemuan pertama guru memperkenalkan dan menjelaskan Model Pembelajaran Problem Based Learning dengan baik sehingga siswa menjadi antusias untuk mengikuti pembelajaran dengan Model Pembelajaran Problem Based Learning. Namun guru belum sepenuhnya melaksanakan pembelajaran pada kompetensi Mengelola Kartu Persediaan dengan Model PembelajaranProblem Based Learning sesuai dengan yang peneliti rencanakan dalam RPP.

Prestasi Belajar Akuntansi siswa setelah penerapan Model Pembelajaran Problem Based Learning pada kompetensi Mengelola Kartu Persediaan diukur dengan memberikan tes pada akhir siklus I yaitu pada pertemuan kedua. Tujuan yang ingin dicapai dari pemberian tes ini adalah melakukan pengukuran sejauh mana penguasaan siswa terhadap materi pelajaran yang dilaksanakan dengan penerapan Model Pembelajaran Problem Based Learning. Ketuntasan Prestasi Belajar Akuntansi pada siklus I dapat dilihat pada tabel 3 berikut ini:

Tabel 3. Penggolongan Ketuntasan Prestasi Belajar Akuntansi pada Siklus I

\begin{tabular}{|c|c|c|}
\hline $\begin{array}{c}\text { Rentang Nilai } \\
\text { Produktif }\end{array}$ & $\begin{array}{c}\text { Jumlah Siswa } \\
\text { Tuntas }\end{array}$ & $\begin{array}{c}\text { Jumlah Siswa } \\
\text { Belum Tuntas }\end{array}$ \\
\hline $75,0-100$ & 13 & 0 \\
\hline $0-74,9$ & 0 & 8 \\
\hline Jumlah & 13 & 8 \\
\hline Persentase & $61,90 \%$ & $38,10 \%$ \\
\hline
\end{tabular}

Berdasarkan nilai pada siklus I yang diperoleh dari lampiran 10 halaman 139 dapat dihitung sebagai berikut:

$$
\begin{aligned}
& \text { Nilai rata-rata kelas } M=\frac{\sum F x}{N} \\
& \qquad M=\frac{1490}{21}=70,95
\end{aligned}
$$

Rincian nilai pada tabel diatas. Dari tabel prestasi belajar di atas dapat disimpulkan bahwa siswa yang telah mencapai KKM yang telah ditetapkan oleh sekolah yaitu sebesar 75, 
telah dicapai oleh 13 siswa atau sebesar $61,90 \%$ dan diperoleh rata-rata nilai akuntansi pada kompetensi Mengelola Kartu Persediaan oleh siswa kelas XI Akuntansi pada siklus I sebesar 70,95. Bila dibandingkan dengan nilai siswa sebelum dilaksanakannya penerapan Model Pembelajaran Problem Based Learning yaitu sebagai berikut:

Tabel 4. Penggolongan Ketuntasan Prestasi Belajar Akuntansi sebelum dilaksanakan penerapan Model Pembelajaran Problem Based Learning

\begin{tabular}{|c|c|c|}
$\begin{array}{c}\text { Rentang Nilai } \\
\text { Produktif }\end{array}$ & $\begin{array}{c}\text { Jumlah Siswa } \\
\text { Tuntas }\end{array}$ & $\begin{array}{c}\text { Jumlah Siswa } \\
\text { Belum } \\
\text { Tuntas }\end{array}$ \\
\hline $75,0-100$ & 9 & 13 \\
\hline $0-74,9$ & & 13 \\
\hline Jumlah & 9 & $59,09 \%$
\end{tabular}

Berdasarkan nilai sebelum adanya tindakan yang diperoleh dari tabel di atas dapat dihitung sebagai berikut:

$$
\begin{aligned}
& \text { Nilai rata-rata kelas } M=\frac{\sum F x}{N} \\
& \qquad M=\frac{1544}{22}=69,36
\end{aligned}
$$

Rincian nilai pada tabel diatas terlampir pada lampiran 10 halaman 139. Berdasarkan data Prestasi Belajar Akuntansi kompetensi Mengelola Kartu Persediaan sebelum dilaksanakan penerapan Model Pembelajaran Problem Based Learning diatas, maka dapat disimpulkan prestasi belajar siswa pada tindakan siklus Isudah mengalami peningkatan pada nilai rata-rata sebesar 1,59. Meskipun demikian prestasi belajar siswa pada siklus I belum optimal karena nilai rata-rata kelas masih belum mampu mencapai KKM yang telah ditetapkan yaitu sebesar 75 .

\section{Hasil Penelitian Siklus II}

Prestasi Belajar Akuntansi siswa setelah penerapan Model Pembelajaran Problem Based Learning kompetensi Mengelola Kartu Persediaan diukur dengan memberikan post test pada akhir siklus II. Tujuan yang ingin dicapai dari pemberian tes ini adalah melakukan pengukuran sejauh mana penguasaan siswa dengan penerapan Model Pembelajaran Problem Based Learning. Hasil Prestasi Belajar Akuntansi pada siklus II dapat dilihat pada tabel 5 berikut ini:

Tabel 5. Penggolongan Ketuntasan Prestasi Belajar Akuntansi pada Siklus II

\begin{tabular}{|c|c|c|}
\hline $\begin{array}{c}\text { Rentang Nilai } \\
\text { Produktif }\end{array}$ & $\begin{array}{c}\text { Jumlah Siswa } \\
\text { Tuntas }\end{array}$ & $\begin{array}{c}\text { Jumlah Siswa } \\
\text { Belum } \\
\text { Tuntas }\end{array}$ \\
\hline $75,0-100$ & 21 & 0 \\
\hline $0-74,9$ & 0 & 1 \\
\hline Jumlah & 21 & 1 \\
\hline Persentase & $95,45 \%$ & $4,55 \%$ \\
\hline
\end{tabular}

Rincian nilai pada tabel diatas terlampir pada lampiran 10 halaman 139. Dari tabel Prestasi Belajar Akuntansi di atas pada kompetensi Menglolaa Kartu Persediaan, siswa yang mencapai KKM sebanyak 22 siswa atau sebesar 95,45\% dan diperoleh rata-rata kelas pada akhir siklus II yaitu sebesar 93,86. Jika membandingkan Antara sebelum menerapkan Model Pembelajaran Problem Based Learning, pada siklus I, dan pada siklus II, maka dapat dilihat bawa terjadi peningkatan yang signifikan pada siklus II. Nilai rata-rata kelas pada siklus I hanya sebesar 70,95, pada siklus II naik menjadi 93,86, atau meningkat sebesar 22,91. Perbandingan 
nilai antara sebelum menerapkan Model Pembelajaran Problem Based Learning, pada siklus I, dan pada siklus II adalah sebagai berikut:

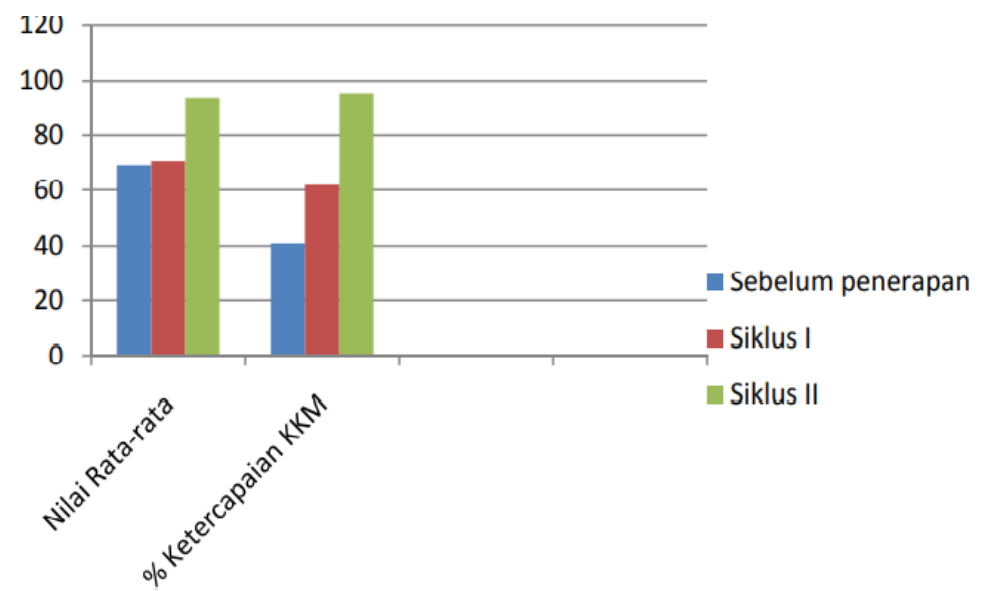

Gambar 1. Diagram Perbandingan Prestasi Belajar Akutansi Siswasebelum dan sesudah dilakukan tindakan.

Model Pembelajaran Problem Based Learning diterapkan pada proses pembelajaran kompetensi Mengelola Kartu Persediaan. Secara umum proses pembelajaran dengan penerapan Model ini diawali dengan memberikan apersepsi kepada siswa tentang materi yang akan dipelajari oleh siswa pada setiap awal pertemuan. Kegiatan inti pembelajaran dilakukan dengan pemberian kasus atau permasalahan yang harus dipecahkan dengan diskusi kelompok. Selama kegiatan diskusi, guru dan peneliti berusaha mendorong siswa untuk menemukan jawaban atas solusi melalui aktivitas pemecahan masalah yang bermakna bagi siswa. Dalam pemecahan aktivitas masalah dengan diskusi kelompok tersebut setiap kelompok diminta untuk melakukan pembagian siswa yang dapat membuat setiap anggota kelompok dalam berperan aktif dalam upaya pemecahan masalah. Siswa diminta untuk bertanggung jawab atas apa yang menjadi tugasnya, bekerja sama dengan teman satu kelompok serta berbagi ilmu untuk menyelesaikan kasus yang disajikan. Kegiatan diskusi kelompok dilanjutkan dengan presentasi jawaban atau solusi atas permasalahan dari hasil diskusi kelompok. Melalui presentasi kelompok ini dapat dilihat alternatif jawaban yang diajukan setiap kelompok. Alternatif jawaban tersebiut selanjutnya dibahas kembali dalam diskusi kelas yang dipandu oleh guru.

Hasil penelitian ini diperkuat oleh teori dari para ahli. Berdasarkan teori dari beberapa ahli faktor-faktor yang mempengaruhi prestasi belajar akuntansi dapat digolongkan menjadi faktor internal dan faktor eksternal. Faktor eksternal yang mempengaruhi Prestasi Belajar Akuntansi yaitu faktor sekolah yang salah satunya meliputi metode mengajar. Apabila metode mengajar guru disesuaikan dengan kondisi kelas maupun materi yang diajarkan maka prestasi belajar secara otomatis akan meningkat. Menurut Taufiq Amir (2009: 27), penerapan Model PembelajaranProblem Based Learning memiliki beberapa kekuatan, antara lain; 1) Fokus kebermaknaan, bukan fakta (deep versus surface learning) 2) Meningkatkan kemampuan siswa untuk berinisiatif 3) Pengembangan keterampilan dan pengetahuan 4) Pengembangan keterampilan interpersonal dan dinamika kelompok.

Yatim Riyanto (2010: 291) menyebutkan indikasi kemandirian pada Model Pembelajaran Problem Based Learning dapat dilihat dari hal-hal berikut: 1) Siswa dihadapkan pada masalah yang memuat sejumlah konsep dan isu. 2) Siswa diberi kewenangan dan tanggung jawab yang cukup untuk menentukan pilihan tentang topik yang akan dipelajari. 3) Analisis kebutuhan dilakukan secara individual. 4) Dilakukan seleksi terhadap sumber belajar yang akan digunakan. 5) Hasil investigasi yang dilakukan siswa disajikan kepada pihak lain. 6) Partisipasi di dalam evaluasi diri merupakan perilaku SDL (Self Directed Learning) lain yang diharapkan dari siswa. 
Menurut Richard I. Arends (2008:43) Problem Based Learning memiliki dua prinsip utama yang terstruktur, yaitu: 1) Ketrampilan berpikir dan mengatasi masalah, yaitu kegiatan siswa melakukan proses representasi secara simbolis berbagai objek dan kejadian riil dan menggunakan representasi itu untuk menemukan prinsip esensial untuk mengembil alternatif solusi pemecahan masalah. 2) Meniru peran orang dewasa, yaitu dalam melaksanakan Problem Based Learning membantu siswa untuk perform di berbagai stuasi kehidupan nyata dan mempelajari peran-peran orang dewasa yang penting.

Hasil penelitian ini menunjukkan bahwa penerapan Model Pembelajaran Problem Based Learning memberikan respon positif dari siswa sebanyak 97,8\%. Pada indikator sikap siswa terhadap permasalahan yang disajikan sebanyak 18 siswa atau 81,82\% memberikan respon yang positif. Hal ini menunjukan sebanyak 18 siswa atau 81,82\% siswa kelas XI Akuntansi memiliki ketertarikan yang tinggi dan sikap yang cukup antusias terhadap permasalahan atau kasus yang disajikan oleh guru. Pada indikator kemampuan siswa memahami permasalahan dari dunia nyata, sebanyak 19 siswa atau 86,36\% memberikan respon positif dan 3 siswa atau 13,64\% memberikan respon negatif. Hal ini menunjukkan bahwa sebanyak 19 siswa atau 86,36\% siswa kelas XI Akuntansi telah mampu memahami permasalahan atau kasus yang disajikan oleh guru.

\section{KESIMPULAN}

Penerapan Model Pembelajaran Problem Based Learning untuk Meningkatkan Prestasi Belajar Akuntansi Siswa pada Kompetensi Mengelola Kartu Persediaan Kelas XI Akuntansi 1 SMK Negeri 1 Sambas Tahun Ajaran 2017/2018 dapat dikatakan berhasil. Nilai rata-rata Prestasi Belajar Akuntansi siswa sebelum dilakukan tindakan adalah 69,36 dengan persentase ketercapaian KKM sebesar 40,91\%, setelah dilakukan tindakan pada siklus I nilai rata-rata mengalami peningkatan sebesar 1,59 menjadi 70,95 dengan persentase ketercapaian KKM sebesar $61,90 \%$. Pada siklus II nilai rata-rata siswa meningkat menjadi 93,86 dengan persentase atau mengalami peningkatan dari siklus I sebesar 22,91. Penerapan Model Pembelajaran Problem Based Learning dalam pembelajaran Akuntansi kompetensi Mengelola Kartu Persediaan mendapatkan respon yang positif dari siswa kelas XI Akuntansi. Hal ini ditunjukkan dari sikap siswa yang antusias dan bersedia mengikuti langkah-langkah pembelajaran dengan Model Pembelajaran Problem Based Learning selama proses pembelajaran. Berdasarkan jawaban yang diberikan siswa atas pernyataan pada angket, sebagian besar siswa atau lebih dari $75 \%$ memberikan respon yang positif.

\section{DAFTAR PUSTAKA}

Mustakim (2020) Efektivitas Pembelajaran Daring Menggunakan Media Online selama Pandemi Covid-19 pada Mata Pelajaran Matematika. Al asma: Journal of Islamic Education Vol. 2, No. 1.

Susilo.,Herawati dkk (2009). Penelitian Tindakan Kelas Sebagai Sarana Keprofesionalan Guru dan Calon Guru. Malang: Bayumedia

Iskandar. (2009). Penelitian Tindakan Kelas. Jakarta: Gaung Persada Press.

Muhibbin Syah. (2005). Psikologi Belajar. Jakarta: Raja Grafindo Persada

Richard I., Arends (2008) Learning to Teach: Belajar untuk Mengajar terjemahan dari Learning to Teach oleh Helly Prajitno Soetjipto dan Mulyatini Soetjipto. Yogyakarta: Pustaka Pelajar.

Sardiman., AM (2011) Interaksi dan Motivasi Belajar Mengajar. Jakarta: PT. Rajagrafindo Persada.

Setyorini (2011) Penerapan Model Problem Based Learning untuk Meningkatkan Kemampuan Berpikir Kritis Siswa SMP”. Jurnal Pendidikan Fisika Indonesia (Nomor 7). Hlm:52-56.

Taufiq., Amir (2009). Inovasi Pendidikan Melalui Problem Based Learning. Jakarta: Kencana Prenada Media Group.

Yatim., Riyanto (2010) Paradigma Baru Pembelajaran. Jakarta: Kencana 